\title{
Decisive Change or Determined Continuity? The Trump Administration's Foreign and Security Policy Viewed from Central and Eastern Europe
}

\author{
Gábor CSIZMAZIA ${ }^{1}$
}

\begin{abstract}
The election of Donald J. Trump as President of the United States may be viewed as a watershed in American foreign policy. The Trump team entered the White House with several controversial views on America's relation with the outside world, thus raising the question of whether the Trump Presidency will introduce decisive changes or will it follow the tradition of continuity in U.S. foreign policy. Due to some of his provocative remarks on NATO or Russia, President Trump's actual performance is particularly important for Central and Eastern Europeans who have their own respective views on transatlantic relations. The Trump Administration's principle of "America First" has indeed re-evaluated America's responsibilities in the world but has not brought fundamental changes so far. In fact, Central and Eastern Europe may experience U.S. foreign policy continuity in a narrower or wider context alike.
\end{abstract}

Keywords: Trump Administration, transatlantic relations, Central and Eastern Europe, Russia

\section{Introduction}

The outcome of the 2016 U.S. presidential election is regarded as a unique political development for several reasons. The campaign highlighted tensions in U.S. domestic politics: in addition to the divisions of American society on certain issues (such as migration or Obamacare), the race between Hillary R. Clinton and Donald J. Trump represented a confrontation between the "establishment" and the "outsiders". The latter's triumph indicated a sharp change in both the rhetoric and the agenda of the White House. The Trump campaign emphasized the aim of "making America great again" which meant the revision of U.S. investment and burden in its international political, economic and security affairs. Simply put, Donald J. Trump challenged the pillars of the international order that had been established and maintained by the United States, ${ }^{2}$ therefore, the election process was followed with even greater attention by Washington's transatlantic partners. This was particularly true for Central and Eastern Europe where the major security pressures from the East and the South are most direct. Donald J. Trump's views during the campaign on Russia, migration or the American

\footnotetext{
Assistant Lecturer, National University of Public Service; email: csizmazia.gabor@uni-nke.hu The political, economic and security pillars of the international order are the support of democracy, free trade and cooperation through international organizations. According to the liberal theory of international relations, these factors reinforce each-other and underpin international peace. Consequently, some of Donald J. Trump's critical remarks - e.g. praising the leadership qualities of Vladimir V. Putin, rejecting North American Free Trade Agreement (NAFTA) and waving the idea of introducing additional tax on certain imports, or questioning the United States' obligation to defend all NATO allies-have been regarded in the West as challenges against the founding principles of this order.
} 
security umbrella over European NATO allies were outspoken and were giving cause for either concern or relieve in the countries within the region-depending on the specific issue in hand. Nevertheless, while several of the new president's remarks have implied a decisive change in U.S. foreign and security policy, there is - as always - a great chance of some continuity. The aim of this article is to review this dilemma by displaying the major highlights of the Trump Administration's foreign and security policy and their implications on the transatlantic relationship from a Central and Eastern European perspective.

\section{The Trump Administration's Heritage in Central and Eastern Europe}

In order to have a clear view on the main possibilities for the Trump Administration's position toward Central and Eastern Europe, its predecessors' respective views should be observed in the wider context, namely the main strategic thought of previous U.S. administrations. Accordingly, the following paragraphs will focus on the background and the rationale of Washington's policy concerning the region after the Cold War.

\section{Central and Eastern Europe on the Previous Administrations' Agenda}

By the time William J. Clinton entered the White House, the dissolution of the Soviet Union and the Warsaw Pact left NATO in search for a role in the post-bipolar world. Moreover, the disappearance of these powers created a security vacuum [1: 81] in Central and Eastern Europe with the risk of re-emerging hostilities among nations within the region. The Clinton Administration started to slowly but surely fill this vacuum with NATO which was intended to remain the backbone of transatlantic security. [2] Thus the first post-Cold War NATO enlargement took place in 1999 with Poland, Hungary and the Czech Republic becoming new members of the Alliance. Following the 2001 September 11 terror attacks, the presidency of George W. Bush was inseparable from the global war on terror. The fight against evil [3: 12] taking the form of terrorists and tyrants intending to acquire weapons of mass destruction was in the spotlight of America's foreign and security policy. Washington's focus shifted toward the Middle East, specifically to countries identified as "rogue states". This change also affected NATO expansion: the second round of enlargement in 2004 included seven new members from Central and Eastern Europe, [3: 17-18] as Washington needed allies who could complement U.S. efforts in the "global war on terror". Arguably, ${ }^{3}$ Eastern European countries seeking membership in NATO were viewed as possible providers of niche capabilities. Yet perhaps more importantly, the accession of these nations had a political ${ }^{4}$ aspect as well. This was felt during Europe's division over the support for the Iraqi war in 2003

3 While the overall military capabilities of the new members were relatively insignificant, their contribution in the form of niche capabilities and overflight rights were deemed useful in Washington. [4: 59]

4 According to another view, the Bush Administration was more interested in the political power rather than in the capabilities the new members would bring to the alliance. This perspective was based on experiences such as the operations in Kosovo where the military performance of European allies lagged behind the U.S. efforts. [5: 100-101] 
with Central and Eastern European allies being more eager to stand behind Washington. ${ }^{5}$ This led to an American practice of utilizing NATO as a toolbox which caused tension in the transatlantic relationship and was ultimately counterproductive.

Barack H. Obama promised a fresh start in transatlantic relations. For Central and Eastern European nations, the new American approach was perceived as a less pleasant development. The Obama Administration showed signs of losing interest in the region and was more focused on withdrawing from the Middle East and conducting a "pivot" toward the Asia Pacific. ${ }^{6}$ In addition, Washington's emphasis was set on global issues such as climate change and nuclear non-proliferation. ${ }^{7}$ This led to the "reset" with Russia which was primarily aimed at cooperation on shared security challenges, including international terrorism and the spreading of weapons of mass destruction. The latter issue provided the highlight of the "reset", the 2010 New START. While the Obama Administration continued enlarging NATO, and opposed the idea of a Russian sphere of influence in Eastern Europe, allies in the region were wary of the realist pragmatism of Washington. They were afraid that while taking the Euro-Atlantic orientation of the countries within the region for granted, Washington might make a deal with Moscow over their heads. The White House did rush to reassure these allies in October 2009, however, it also made it clear that America expects more from Europe and that the region is not exempt from this. ${ }^{8}$ This was a reconfirmation that due to its global agen$\mathrm{da}$, the Obama Administration was focusing less on Central and Eastern Europe. Russia's interference in Ukraine was a watershed, as it led to an increased NATO presence on the Eastern flanks of the Alliance with the United States being the first NATO member to make military reassurance measures in the Baltics, Poland and Romania via the European Reassurance Initiative. This could be regarded as a sharp turn in Washington's policy, although the nature of U.S. military presence in the region has remained the same. ${ }^{9}$ The relationship of the United States with Russia on the other hand has further deteriorated.

5 From the Bush Administration's perspective, former communist countries in Europe were adamant allies, as they held freedom and western values in high regard, precisely due to their historical experience of repression. [3: 20]

6 The Obama Administration's decision sent an unpleasant message to European allies thus the term "pivot" was softened to "rebalance" albeit the policy remained the same. One of the first announcements of the “pivot” was Secretary of State Hillary R. Clinton's article “America’s Pacific Century” in the 2011 November issue of Foreign Policy, however, President Obama’s remarks in Australia the same month were also outspoken: "I have directed my national security team to make our presence and mission in the Asia Pacific a top priority. As a result, reductions in U.S. defense spending will not-I repeat, will not—come at the expense of the Asia Pacific.” [6]

7 President Obama's security policy priorities included the efforts for a world without nuclear weapons, announced in his remarks in Prague and Berlin on the $5^{\text {th }}$ of April 2009 and the $19^{\text {th }}$ of June 2013 respectively.

$8 \quad$ In Vice President Joseph R. Biden's words: "we no longer think in terms of what we can do for Central Europe, but rather in terms of what we can do with Central Europe.” [7]

9 In order to avoid higher costs and the further escalation of the conflict with Russia, there was a debate on the actual form of reassurance, specifically about its size and time-span. This led to a persistent rotational deployment of land, air and sea forces (instead of permanent large deployments) via trainings and exercises, positioning of equipment and improvements in infrastructure. This is in line with the 2012 U.S. Defense Strategic Guidance which in general called for developing "innovative, low-cost, and small-footprint approaches to achieve our security objectives, relying on exercises, rotational presence, and advisory capabilities”. [8: 3] 


\section{The Russia Factor}

Washington's relationship with Moscow is an important component in clarifying the U.S. stance toward Central and Eastern Europe. In fact, the latter is often viewed in the context of the former. Through its geographical size and position, military capabilities and political clout, Russia is a player the United States does not ignore in global affairs. Accordingly, American administrations in the last couple of decades have laid special emphasis on Russia, so much so that this emphasis often enjoyed priority over the focus on Central and Eastern Europe, meaning the idea of "Russia First" in U.S. foreign policy. [9: 59] Facing the critique that NATO's enlargement could alienate the already wary Moscow from the West, the Clinton Administration called for the 1997 NATO-Russia Founding Act which was meant to clarify the post-Cold War relationship between the alliance and its former adversary. ${ }^{10}$ George W. Bush acknowledged Russia as a great power ${ }^{11}$ and recognized the importance of the strategic bilateral relationship in the sphere of arms reduction, and especially in the light of the threat by rogue actors in the international system. ${ }^{12}$ Yet the concerns regarding democracy and human rights in Russia, the American position on Kosovo's independence and missile defence represented serious clashing points in U.S.-Russia relations. ${ }^{13}$ The Bush Administration also pushed for the invitation of Ukraine and Georgia into the Alliance. This not only divided European NATO members but angered Russia ${ }^{14}$ whose five-day war with Georgia in 2008 indicated the lowest point in U.S.-Russia relations since the Cold War at the time. For Central and Eastern European nations, the events only reconfirmed their views that Russia continues to claim its former sphere of influence- - backing it up with force - and that therefore the transatlantic bond should be enhanced.

President Obama's election in 2008 promised change in many areas, including the relationship with Russia albeit in a modest way. Throughout the campaign Barack H. Obama was increasingly condemning the Russian aggression against Georgia, and was clearly supporting U.S. missile defence in Central Europe. ${ }^{15}$ On the other hand, he seemed more open to cooperation with Russia on certain issues such as arms control or the fight against terrorism. Overall, the Democrat nominee enjoyed more confidence in Russia with the possibility of a fresh start. The latter came in the form of the "reset" which was the Obama Administration's attempt to reaching out to President Medvedev's Russia. Announced by

10 President Boris N. Yeltsin's remarks of the agreement showed the limits of Russian enthusiasm: "We believe that the eastward expansion of NATO is a mistake and a serious one at that. Nevertheless, in order to minimize the negative consequences for Russia, we decided to sign an agreement with NATO.” [10]

11 "In the breadth of its land, the talent and courage of its people, the wealth of its resources, and the reach of its weapons, Russia is a great power, and must always be treated as such.” [11: 29]

12 "Instead of confronting each other, we confront the legacy of a dead ideological rivalry-thousands of nuclear weapons, which, in the case of Russia, may not be secure. And together we also face an emerging threatfrom rogue nations, nuclear theft and accidental launch. All this requires nothing short of a new strategic relationship to protect the peace of the world.” [11: 29-30]

13 The Bush Administration's plans for enhancing America's-and NATO's—ballistic missile defence system included the deployment of a radar facility and ten interceptors in the Czech Republic and Poland respectively. While the idea was viewed controversial even in the host countries, they eventually signed up for the plan irritating Russia which regards the establishment of these military installations as potential threats.

14 "Welcoming [Ukraine and Georgia] into the Membership Action Plan would send a signal [...] throughout the region that these two nations are, and will remain, sovereign and independent states.” [12]

15 The Obama campaign specifically noted that while missile defence is necessary, the Bush Administration's plans in Central Europe should be revised. 
Vice President Joseph R. Biden ${ }^{16}$ at the $45^{\text {th }}$ Munich Conference on Security Policy in 2009, the 'reset' was aimed at bringing forward the aforementioned areas of cooperation with Russia but without appeasement from Washington in other issues such as acknowledging a Russian sphere of influence in Eastern Europe. ${ }^{17}$ Still, the "reset" has received mixed views in Central and Eastern Europe. ${ }^{18}$ President Obama's 2009 September decision to alter his predecessor's missile defence plans in Poland and the Czech Republic was not unexpected, nevertheless, it did not help the situation..$^{19}$ The "reset" did have its achievements during President Obama's first term including the New START Treaty and Russia's WTO accession. Furthermore, the 2012 U.S. presidential elections showed that President Obama is less wary of Russia than his Republican opponent. ${ }^{20}$ Yet by the same year the "reset" became exhausted: Vladimir V. Putin blamed Secretary of State Hillary R. Clinton for inciting protests after the Russian legislative elections in December 2011, and-a year later-Secretary Clinton openly opposed the Russian integration project in Eastern Europe and Asia. ${ }^{21}$ Legislative branches of the two governments did not embrace each other either: in response to the Senate's approval of the Magnitsky Act (introducing sanctions in finance and travel against Russian officials who had contributed to the death of Russian whistle-blower Sergei Magnitsky), the Duma approved the Dima Yakovlev Law (banning U.S. citizens from adopting Russian children). [16] This geopolitical opposition culminated in Eastern Europe through the events in Ukraine, leaving U.S.-Russia bilateral relations in the cold for the 2016 U.S. presidential elections.

\section{The Trump Administration and Central and Eastern Europe}

In order to highlight the outlooks of transatlantic relations under the Trump presidency from a Central and Eastern European perspective, it is essential to outline the principles of the Trump administration's foreign policy. With the exception of Russian attempts to influence the U.S. presidential elections, the international security environment has not displayed

16 "[I]t's time to press the reset button and to revisit the many areas where we can and should be working together with Russia.”[13]

17 "We will not agree with Russia on everything. [...] We will not recognize any nation having a sphere of influence. It will remain our view that sovereign states have the right to make their own decisions and choose their own alliances." [13]

18 "We welcome the "reset" of the American-Russian relations. As the countries living closest to Russia, obviously nobody has a greater interest in the development of the democracy in Russia and better relations between Moscow and the West than we do. But there is also nervousness in our capitals. We want to ensure that too narrow an understanding of Western interests does not lead to the wrong concessions to Russia.” [14]

19 While the Obama Administration was adamant that the decision was not meant to appease Russia, the way it was announced was questionable. Firstly, whereas President Obama declared his decision in a television announcement in the United States, the Government of Poland was informed via a phone call in the middle of the night. Secondly, the sensitive announcement came on the 17th of September-the day on which the Soviet Union began the invasion of Poland in 1939 (in accordance with its secret pact with Germany). Lastly, while neither the change in U.S. missile plans nor the attempt to mend NATO-Russia relations was a surprise, the latter was announced just one day later through the first major public speech by Secretary General Anders F. Rasmussen titled "NATO and Russia: A New Beginning”.

20 One of the highlights of the 2012 U.S. presidential election campaign was when Republican presidential nominee Willard Mitt Romney called Russia America’s “geopolitical foe”, a position which President Obama deemed outdated, saying that "the 1980s are now calling to ask for their foreign policy back" in the third presidential debate on the 22nd October 2012.

21 Secretary Clinton deemed the Russian plans for a Eurasian Union as attempts to "re-Sovietise the region.” [15] 
qualitatively new major challenges to the Trump presidency. President Trump on the other hand introduced a drastically new approach to the already existing issues and toward the outside world.

\section{President Trump's View of America and the World}

Although the 2016 presidential election campaign was loud of scandals and personalities on both sides, it did highlight several pressing foreign and security policy issues of today's America which the Trump Administration has set on its agenda. The primary items on this list of challenges include illegal immigration, international terrorism and the negative effects of American leadership in the world (i.e. the costs of international security) and of economic globalization (i.e. the loss of American jobs and an increasing U.S. trade deficit). The Trump team's position and rhetoric on these issues have two defining characteristics: on the one hand, all of them directly affect the American public in their everyday lives and were addressed in the campaign accordingly. On the other hand, all of these problems were linked with the Obama Administration (and previous governments) by the Trump campaign. As a result, Donald J. Trump promised a decisive departure from President Obama's foreign policy which he described as a random one without vision, purpose and thought-through strategy, and one leading to the lack of respect towards Washington from friends and foes alike. [17] The first and foremost important change President Trump intends to introduce is the dismissal of an active liberal approach on a global level.

In practical terms, this means two things. Firstly, defying "the false song of globalism", President Trump believes that "the nation-state remains the true foundation of happiness and harmony". [17] This seemingly set Washington once again at the juncture of internationalism and isolationism which is a re-occurring dilemma in American foreign policy debates. However, President Trump is not an isolationist but rather a nationalist who intends not to end but to alter America's economic and security relationship with others - be it allies, partners or potential adversaries - to its own advantage. ${ }^{22}$ The "America First" approach ultimately raises the question of the United States' role in the world. In Washington, American leadership has been a widely accepted component of the international order. On paper, the Trump Administration is no different in this regard with President Trump emphasizing America's capability to lead. ${ }^{23}$ Yet due to its aforementioned nationalist perspective, the Trump Administration's aptitude for global leadership has received doubts. A recent example for this was when President Trump decided to withdraw the United States from the 2016 Paris Agreement on the joint efforts to combat climate change - a decision which caused widespread disappointment among members of the international community. Still, international trade deals find themselves even more in the crossfire of the Trump Administration. President Trump has promised to revisit America's hitherto international arrangements in trade and economy. In practical terms, this means a new take on free trade agreements and reshape or even nullify those that are disadvantageous for the United States. President Trump's main targets in this

22 "We will respect historical institutions, but we will respect the foreign rights of all nations, and they also have to respect our rights as a nation also. Free nations are the best vehicle for expressing the will of the people, and America respects the right of all nations to chart their own path. My job is not to represent the world. My job is to represent the United States of America.” [18]

23 "Our allies will find that America is once again ready to lead. All the nations in the world—friend or foe-will find that America is strong, America is proud, and America is free.” [18] 
regard were the 1994 NAFTA between the United States, Canada and Mexico, and the 2016 (signed) Trans-Pacific Partnership (TPP) between the United States and 11 other nations bordering the Pacific Ocean. While NAFTA can expect renegotiations, American participation in TPP was actually abandoned on President Trump's first day in office.

Secondly, the Trump Administration denounced the "global projects" of its predecessors, and specifically urged for "getting out of the nation-building business", particularly in the Middle East. [18] In other words, the Trump Administration is not in favour of democracy promotion abroad, in fact, it regards such attempts as sources of destabilization in the Middle East which enabled the rise of additional extremist groups such as the Islamic State of Iraq and Syria (ISIS). ${ }^{24}$ Instead, President Trump focuses on international terrorism under radical Islam with one of his first decisions being to task the Administration "to develop a comprehensive plan to defeat ISIS". [19] The war against terrorism is among the top security policy priorities for the Trump Administration who has continued to rally allies for the U.S.-founded Global Coalition to Counter ISIS. So much so that one of President Trump's main goals and achievements at his first NATO summit was the Alliance's formal inclusion into this coalition. In a certain sense, this development offers nothing substantially new, as all NATO members were already members of the coalition. However, it does reveal President Trump's view of NATO. During the campaign, he called the Alliance "obsolete" for having an anachronistic mission instead of fighting international terrorism. President Trump's first change of heart came in April 2017 when he indicated that NATO as an organization does agree with him on fighting against terrorism. ${ }^{25}$ In reality, the Alliance has already been contributing to the war on terror, although several member states were wary that NATO's formal inclusion into the Global Coalition to Counter ISIS would serve with more problems rather than solutions. So far, the end result of President Trump's first NATO summit in this regard was a decisive yet limited support from European allies. ${ }^{26}$

\section{Implications for the Transatlantic Relationship and Russia}

European cautiousness is a by-product of the Trump Administration's foreign and security policy. In President Trump's eyes, the aforementioned U.S. efforts aimed at more fair deals cannot exclude the area of defence. Specifically, America's allies need to display more responsibility for their respective security by increasing their defence spending and thereby decreasing their reliance on American support. Next to NATO's role in the fight against terrorism, this was President Trump's main message at the Brussels summit in May 2017. [22] America's demand for a more equal transatlantic burden-sharing in security is not new at all.

24 "We went from mistakes in Iraq to Egypt to Libya, to President Obama's line in the sand in Syria. Each of these actions have helped to throw the region into chaos, and gave ISIS the space it needs to grow and prosper. It all began with the dangerous idea that we could make Western democracies out of countries that had no experience or interest in becoming a Western democracy. We tore up what institutions they had and then were surprised at what we unleashed. Civil war, religious fanaticism; thousands of American lives, and many trillions of dollars, were lost as a result. The vacuum was created that ISIS would fill.” [17]

25 "The Secretary General and I had a productive discussion about what more NATO can do in the fight against terrorism. I complained about that a long time ago and they made a change, and now they do fight terrorism. I said it was obsolete; it's no longer obsolete. It's my hope that NATO will take on an increased role in supporting our Iraqi partners in their battle against ISIS.” [20]

26 In addition to the political message of its support, NATO would enhance its efforts in surveillance, anti-terror intelligence, and in training but would not participate in combat operations. [21] 
Before President Trump, former U.S. Secretary of Defence Robert M. Gates set the frank reminder about this several decades-old reality. ${ }^{27}$ The novelty of Donald J. Trump's position was that he openly questioned the U.S. obligation to follow NATO's Article 5, making it dependent on the defence spending performance of the attacked ally in question. [24] Accordingly, the Trump Administration's commitment to collective defence was an awaited statement in Brussels. While President Trump remained silent on this at the NATO summit, he ultimately re-confirmed U.S. commitment to collective defence, and in fact argued that the constant reminders of members' responsibility to pay $2 \%$ of their respective GDP on defence was for the greater good of having an overall stronger Alliance. ${ }^{28}$

Whereas President Trump's statements on certain issues such as climate change has raised doubts about his government's ability of international leadership in Western Europe (specifically in France and Germany), U.S. allies in Central and Eastern Europe are more interested in the Trump Administration's reliability, especially in security and defence. From a Central and Eastern European perspective, U.S. commitment to Article 5 is the cornerstone of transatlantic relations. Thus, the President's earlier remarks on NATO and collective defence should have provided ground for worries in these countries. Yet there is an important principle in this regard: words and actions need to be distinguished. After Mr Trump's campaign statement on tying American defence of allies to their respective financial contribution to that defence, Hillary R. Clinton emphasized that "words matter when you run for President, and they really matter when you are President [and] it is essential that America's word be good" [26] thereby stressing the possible negative consequences of such remarks. However, even in the wake of NATO's Brussels meeting where the reassuring words on collective defence were missing, the Alliance's eastern flank did not give an echo of concern. This was due to the fact that American commitment to NATO's Article 5 is openly supported by both Secretary of Defence (Ret. Gen.) James N. Mattis and Secretary of State Rex W. Tillerson but more importantly, regardless of any statements, the United States continued to send troops to Eastern European member states. ${ }^{29}$ In fact, the Trump Administration's defence budget request for fiscal year 2018 included an increase of $\$ 1.4$ billion for the European Reassurance Initiative (ERI) thus planning with an ERI budget growth of nearly $41 \%$. While this increase is not as massive as the Obama Administration's increase ${ }^{30}$ for 2017 , it does show the continuing American

27 "The blunt reality is that there will be dwindling appetite and patience in the U.S. Congress - and in the American body politic writ large - to expend increasingly precious funds on behalf of nations that are apparently unwilling to devote the necessary resources or make the necessary changes to be serious and capable partners in their own defense. Nations apparently willing and eager for American taxpayers to assume the growing security burden left by reductions in European defense budgets.” [23]

28 "I have been an advocate for strengthening our NATO Alliance through greater responsibility and burdensharing among member nations. [...] I'm committing the United States to Article 5. And certainly we are there to protect. And that's one of the reasons that I want people to make sure we have a very, very strong force by paying the kind of money necessary to have that force.” [25]

29 For example, while Slovak Minister of Foreign and European Affairs Miroslav Lajčák said that although he would have preferred to hear President Trump's devotion to collective defence, "the commitment under Article 5 is so obvious there was no need to mention it”, Polish Minister of Foreign Affairs Witold Waszczykowski remarked that American boots on the ground in Poland are "much better than just a declaratory mention of Article 5. I prefer to have 5,000 troops from the United States in Poland. This is a commitment”. [27]

30 ERI was announced in June 2014 by President Obama whose Administration initially received \$985 million for 2015. While in 2016 the ERI budget decreased to \$789 million, the Obama Administration successfully requested an increase, eventually almost quadrupling the overall budget to \$3.4 billion in 2017. [28] 
interest in enhancing allied military presence, readiness and capabilities on Europe's Eastern Flank (including the defence capabilities of Ukraine).

The increased ERI budget means that U.S. military presence in Central and Eastern Europe in the form of forward positioned forces and exercises is assured until 2020. However, it is noteworthy to mention that this continued financial support may not necessarily lead to an increase in U.S. troop numbers. [29] Due to this limitation in American numbers, the focus is set on the "speed of assembly" i.e. the time required for moving U.S. and allied forces from one place to another. Hitherto exercises served this purpose as well. Two examples of the earlier exercises continued under the Trump Administration are Saber Guardian and Saber Strike. The former represented the largest exercise held in Europe in 2017 with 25,000 U.S. soldiers cooperating with 24 nations between 11-20 July in Hungary, Romania and Bulgaria [30] whereas the latter was held between 28 May and 24 June in Poland and the Baltics with 11,000 U.S. and allied troops. [31] One of the lessons of these exercises was that the allied troops' peacetime border-crossings continue to face infrastructural and bureaucratic difficulties and that the latter could be eased by the establishment of a "military Schengen zone" within NATO. This American observation [32] was already made in 2015 by Commander of U.S. Army Europe Lt. Gen. Ben Hodges, however, it has begun to circulate among European stakeholders as well. [33]

The other major form of American military presence in Central and Eastern Europe is via the U.S. missile defence sites in the Republic of Poland and Romania. The Obama Administration's plans for the European Phased Adaptive Approach (EPAA) is scheduled to be completed in 2018, however, due to the manifold factors ${ }^{31}$ possibly impacting its development, the U.S. missile shield in Europe may be altered by the Trump Administration. That said, little is known of President Trump's view on the subject so far. Before assuming office, Donald J. Trump promised to "fully eliminate the defense sequester" as well as to "develop a state of the art missile defense system" in response to the threats from Iran and North Korea. [35] The Kim regime's missile tests have led President Trump to call for an increase in the budget for missile defence, although Congress has proven to be more eager in this regard: by mid-September 2017 both the House and the Senate have passed their respective versions of the National Defense Authorization Act for Fiscal Year 2018, overbidding the President by allocating $\$ 8.5$ billion for the Missile Defense Agency within a nearly $\$ 700$ billion overall defence budget. [36] This is especially interesting when taken into account that the Pentagon's Ballistic Missile Defence Review was not finished by the time of voting. The document is of high importance, as it serves the purpose of providing information on the possibilities for further improving U.S. missile defence capabilities, and therefore, offering implications for the fate of President Obama's EPAA schedule which has not been addressed by President Trump yet. Missile defence also raises the issue of nuclear weapons: for Russia, NATO's ballistic missile defence in Europe - as well as the intensified military presence in the region-has served as a reason to deploy nuclear-capable missiles closer to NATO

31 The core concept of the European Phased Adaptive Approach is that U.S. missile defence plans in Europe can be altered at any stage depending on the change in security climate, available technical capabilities or financial framework. In practical terms, the EPAA's further realization may be affected by the security relationship with Iran, the developments in American missile technology and the U.S. Government's-legislative and executive branches'-position on providing additional funding for missile defence. In addition, fierce Russian objection against the plan and the possible consequences of this opposition set the Central European missile shield in the spotlight of international security. [34] 
members, thereby increasingly undermining such arms control regimes as the 1987 INF Treaty. Similarly, to the eventual development of missile defence, the changes in America's nuclear posture - and its effects in Europe - under the Trump Administration depends on several factors: firstly, despite President Trump's intention to make-up with Russia, he has denounced the Russian violation of the INF Treaty. While Central and Eastern European countries are highly interested in constraining nuclear weapons within their own region, they are also dependent on NATO's nuclear umbrella. Subsequent to the crisis in Ukraine, Poland was reported to consider participating in NATO's 'nuclear sharing' programme, although this was ultimately denied by the Polish Government. [37] Secondly, Donald J. Trump has called for the enhancement of the United States' nuclear arsenal while also hinting that the 2010 New START was a "just another bad deal" of the Obama Administration [38] which is an alarming note concerning future arms reduction agreements. Nevertheless, just like in the case of missile defence, the exact position of the U.S. Administration on the American nuclear capabilities will be revealed in the Pentagon's - currently ongoing-Nuclear Posture Review.

Politically speaking, NATO allies in this region are particularly important for the Trump White House, as many of them can be set as examples for increasing national defence budgets. It is no surprise that President Trump's first trip to the region was to Poland which is one of the few Alliance members having their national defence expenditure reached $2 \%$ of GDP. ${ }^{32}$ While his address to the people of Poland was primarily focused on defending Western civilization from such major threats as radical Islam and international terrorism, President Trump also spoke about the threat posed by Russia. ${ }^{33}$ Apart from confirming U.S. devotion to NATO's Article 5, the Trump Administration came closer to reaching an agreement with Poland on the purchasing of medium-range Patriot missiles for the latter's air defence system, as well as to initiating U.S.-Polish efforts aimed at modernizing the Polish Armed Forces. Other Central and Eastern European nations are also looking ahead of modernizing their respective air and missile defences which could open the door for enhancing the security relationship with the U.S. [40] Yet these ties can reach into the sphere of economy as well. President Trump's Warsaw visit included his participation at the Three Seas Initiative ${ }^{34}$ Summit of Central and Eastern European countries. President Trump expressed his support for providing U.S. assistance in these nations' efforts for energy security by selling American liquefied natural gas (LNG) to them. [41] While this is a long-awaited development in Poland and the Baltics, its roots are actually found at the Trump Administration's energy policy. One of Donald J.

32 The geopolitical aspect is also worthy of mentioning: due to their respective geographical position and to their size in territory and population, Romania and Poland enjoy special attention from Washington within the region and pursue strongly Atlanticist foreign policies. Accordingly, President Trump's first bilateral meeting with leaders from Central and Eastern Europe was held with President Klaus Iohannis of Romania and President Andrzej Duda of Poland on the $9^{\text {th }}$ of June and on the $6^{\text {th }}$ of July 2017 respectively.

33 “Today, the West is also confronted by the powers that seek to test our will, undermine our confidence, and challenge our interests. To meet new forms of aggression, including propaganda, financial crimes, and cyberwarfare, we must adapt our alliance to compete effectively in new ways and on all new battlefields. We urge Russia to cease its destabilizing activities in Ukraine and elsewhere, and its support for hostile regimes_-including Syria and Iran — and to instead join the community of responsible nations in our fight against common enemies and in defense of civilization itself.” [39]

34 The Three Seas Initiative is an informal platform aimed at supporting regional economic, energetic, transportation and communication projects in the wider region of Central and Eastern Europe, specifically among countries in-between the Baltic, the Adriatic and the Black Sea. 
Trump's campaign promises was to revive the coal, oil and gas industry in America and to boost their exports. In the case of shale gas and LNG, this requires U.S. Energy Department permits for special facilities and shipment. [42] Accordingly, the Trump Administration went ahead by loosening legislation in this area, making it easier for U.S. companies to extract and export coal, oil and gas. ${ }^{35}$ Selling American gas would have a major effect in the security of Central and Eastern Europe. While the motivations of the Trump Administration in this regard are primarily related to creating U.S. jobs and improving balance of trade, the United States would inevitably compete with Russia who has been using the 'energy card' in keeping grip on countries (depending on Russian gas) within the region. ${ }^{36}$

Another important issue for Central and Eastern Europe is how the Trump Administration approaches its transatlantic partners. Specifically, would it regard and treat the European Union as a partner or would it try to bypass the EU and deal with member states one by one? Donald J. Trump's nationalist remarks during the campaign ${ }^{37}$ [17] and his position on Brexit suggest that he is less enthusiastic about the EU, regarding it as an instrument for Germany. ${ }^{38}$ Furthermore, German Chancellor Angela Merkel's policies on trade and immigration received harsh criticism from President Trump. Regarding the first, the U.S. President raised the idea of imposing additional taxes on German products (primarily vehicles) and of rearranging commerce between the two countries. This however cannot be negotiated with the German Federal Government, as negotiating international trade deals are to be done with the European Commission. As for migration, President Trump's views ${ }^{39}$ are closer to the position of several Central and Eastern European countries. That said, it is unlikely that the Bush Administration's notion of "Old and New Europe" would repeat itself. Firstly, while the EU does have its internal debates and problems, Central and Eastern Europeans are not interested in further dividing the Union, as it provides them with better bargaining positions in international relations. Secondly, while the crisis in Ukraine served as a wakeup call in itself for Europeans to increase their national defence budgets, President Trump's view of America's relationship with the world underlined the notion in Central and Eastern European

35 This move is also related to the denouncing of the Obama Administration's energy and climate change policy with President Trump saying that "for the past eight years, the Federal Government imposed massive jobkilling barriers to American energy development. Since my first day in office, I have been moving at record pace to cancel these regulations and to eliminate the barriers to domestic energy production, like never before.” [43]

36 This, however, is a hypothetical situation. While several Central and Eastern European governments share the Trump Administration's enthusiasm on the issue, the actual contracts of LNG purchase are to be signed by specific companies who will only do so if it is financially lucrative. Gas prices have decreased in the last years and Russian gas is already considered relatively cheap due to the proximity of production and the means of transportation (pipes instead of special LNG terminals). Thus, receiving American gas in Central and Eastern Europe will be about the actual price these nations are willing to pay for reducing energy dependency on Russia. [44]

37 "The nation-state remains the true foundation for happiness and harmony. I am sceptical of international unions that tie us up and bring America down and will never enter.” [17]

38 "You look at the European Union and it’s Germany. Basically, a vehicle for Germany. That's why I thought the UK was so smart in getting out [...] I believe others will leave. I do think keeping it together is not gonna be as easy as a lot of people think.” [45]

39 "I think [Chancellor Merkel] made one very catastrophic mistake and that was taking all of these illegals [...] And nobody even knows where they come from.” [45] 
countries that - in addition to the preservation of the transatlantic link - the geopolitical realities make additional integration efforts in security and defence vitally necessary. ${ }^{40}$

One of these realities is Russia ${ }^{41}$ which continued to be in the spotlight of American foreign policy debates, although in a new context. The notion of great power rivalry has remained in place largely due to Russian attempts to interfere in the 2016 U.S. presidential elections. During the campaign, the Trump team represented a more open approach to American-Russian relations, incorporating the traditional idea of fighting against ISIS and terrorism hand in hand. While Donald J. Trump praised the leadership qualities of Vladimir V. Putin, he also utilized this idea in his argument that this was a source of exploitation of America. In other words, despite not being a hardliner on Russia throughout the campaign, Mr Trump indicated that approaching the Russians requires statesmanship with authority (demanding respect) and that some issues - such as cooperation on nuclear non-proliferation - need to be revisited from Washington, since the Obama Administration had reached bad deals with Russia including the 2010 New START Treaty. ${ }^{42}$ The case of Ukraine is similar. Initially, Donald J. Trump called out against the violation of the country's territorial integrity, yet his criticism was largely aimed at the Obama Administration for being weak on the issue. [49] Other members of President Trump's team, including Secretary Tillerson and Ambassador to the United Nations Nikki R. Haley, indicated that while the Trump Administration is seeking better relations with Russia, it continues to condemn Russian actions in Ukraine for which U.S. sanctions will remain in place. [50] Similarly, American-Russian relations have not improved in the case of Syria so far either. Keen on distancing himself from his predecessor regarding the "red line" of chemical weapons, President Trump ordered a military strike against Syrian armed forces on the $7^{\text {th }}$ of April 2017 which the Russian Government unsurprisingly denounced. ${ }^{43}$

While the Trump Administration claims to represent a stronger stance under the motto of 'America First', it is also under pressure from Congress where bipartisan efforts are made to increase sanctions on Russia for its aggression against Ukraine. Hardliners on dealing with Russia have gained momentum within the legislative branch of the American Government following Russia's attempts of meddling with the U.S. presidential elections, and the possi-

40 "The global geopolitical environment is changing fast. Instability in the European Neighborhood, new dynamism on the global level and internal developments in the EU represent challenges the Union needs to address in the spirit of shared interest and responsibility. [...] We should strive for deepening our cooperation in defence and achieving European strategic autonomy. The European defence capabilities have to be developed, while preserving the role of NATO in providing collective defence in Europe. Equally, in order to tackle common geopolitical and security challenges, the Union should strive to strengthen the transatlantic relations and to continue close cooperation with the United Kingdom. We should reaffirm the EU's position as a major global trading partner, advocate an open, rules-based trading system and continue establishing new partnerships based on principles of reciprocity and mutual benefit.” [46]

41 Similarly to his predecessor, President Trump also received an open letter from Central and Eastern European public figures who warned him about President Putin's intentions to loosen the transatlantic bond. [47]

42 "I never met Putin. This is not my best friend. But if the United States got along with Russia, wouldn't be so bad. Let me tell you, Putin has outsmarted [Hillary R. Clinton] and Obama at every single step of the way. Whether it's Syria, you name it. Missiles. Take a look at the 'start up' [New START Treaty] that they signed. The Russians [...] create warheads and we can’t. [...] And all you have to do is look at the Middle East. They've taken over.” [48]

43 U.S. Ambassador to the UN Haley called Russia and Iran responsible for the utilization of chemical weapons in Syria. As for the overall U.S. involvement, like its predecessor, the Trump Administration seems to avoid more direct confrontations in Syria, especially with the Russian forces whom their American counterparts had alerted about the strike in advance. [51] 
bility of linkage between the Trump campaign and the Russian Government. ${ }^{44}$ Accordingly, the Trump Administration has also widened earlier sanctions against individuals through the Treasury Department in parallel with President Trump's meeting with Ukrainian President Petro O. Poroshenko. [53] That said, some in Congress believe that President Trump would be too soft on Russia. Therefore, following the proposal of Democrat and Republican leaders in the Senate, the legislative branch has passed a bill that not only introduced new sanctions against Russian actors involved in the support for the Assad government in Syria or in the hacking of U.S. elections but also called for a Congressional review in case the President would intend to ease hitherto sanctions against Russia by himself. [54] Though calling for Russia's accountability in the aforementioned hacking, Secretary of State Tillerson had asked Congress not to handcuff the Trump Administration in fine-tuning sanctions. [55] President Trump has signed the "Countering America's Adversaries Through Sanctions Act" into law in early August 2017, however, he did emphasize his dislike in the document. ${ }^{45}$ Thus it can be said that President Trump may argue that his White House would engage with President Putin's Kremlin as great powers do, however, the ways of such action do have their limits in the international arena and at home alike.

\section{Conclusion}

Donald J. Trump made sure throughout the 2016 U.S. presidential election campaign that his views vastly differ from the hitherto practices of the establishment - especially Democratsin Washington D.C. Thus in theory, his foreign and security policy should display a noticeable deviation from that of President Obama. Indeed, America's overall stance toward the outside world has been set into new light by the Trump White House. The principle of "America First" does not call an end to American leadership in the world but it does re-evaluate its costs and benefits from a nationalist perspective, and thereby introduces a new approach to international actors, roles and frameworks alike. Nevertheless, the Trump Administration also showed a perpetuation of its predecessors' policies either by repeating older or by continuing recent ideas and practices of U.S. foreign policy. The President's priority focus on the fight against international terrorism is not new, nor is the issue unprecedented on NATO's agenda. In addition, terrorism has once again served as the key driver behind the contemporary U.S. Administration's intention to find common ground with its Russian counterpart which has enjoyed preference by the White House despite other Russia-related issues being unresolved.

Furthermore, although President Trump's critique aimed at European allies for their lagging defence expenditure has been harsh, it does not offer new in content compared to

44 President Trump’s first meeting with President Putin at the G20 summit on July 2017 highlighted this issue perfectly. Regarding the unresolved issue of Russian interference in U.S. elections, Secretary Tillerson noted that the President "rightly focused on how do we move forward from what may be simply an intractable disagreement at this point”. In other words, while the Trump Administration considers the issue problematic, it is also interested in moving on and finding common ground with the Russians in other areas. The same cannot be said of members of Congress, especially Democrats whose Senate Minority Leader Chuck Schumer deemed this position "disgraceful” adding that for President Trump "to give equal credence to the findings of the American intelligence community and the assertion by Mr Putin is a grave dereliction of duty and will only encourage Russia to further interfere in our elections in the future.” [52]

45 While agreeing with the idea of not tolerating the actions of North Korea, Iran and Russia in the respective matters, President Trump noted the bill is "seriously flawed", as it limits his space of manoeuvre in conducting America's foreign policy and may lead to causing collateral damage for U.S. business and European allies. [56] 
Washington's complaints during the Obama-era or even in the last five decades. In contrast to earlier threats of having U.S. commitment to NATO's Article 5 depend on members meeting defence expenditure targets, the Trump Administration has re-confirmed its support for collective defence, moreover, it has continued to back-up this commitment by resources in the form of U.S. troops deployed on the Eastern Flank and an increased ERI budget. These are crucial factors in the calculations of central and eastern European allies when assessing the reliability of the United States.

\section{References}

[1] ALBRIGHT, M.: The Role of the United States in Central Europe. Proceedings of the Academy of Political Science, 38 (1990), 71-84. DOI: https://doi.org/10.2307/1173814

[2] KUSHLIS, H. P. (ed.): Promoting Trans-Atlantic Security through NATO Enlargement. President Clinton Responds to Questions from U.S. Senators. U.S. Foreign Policy Agenda, 4 (1997), 5. http://usembassy-mexico.gov/bbf/ej/1097_NATOEnlargement.pdf (Downloaded: 02.02.2017)

[3] RHODES, E.: Transforming the Alliance: The Bush Administration's Vision of NATO. Connections. The Quarterly Journal, 3 (2003), 11-25.

[4] LARRABEE, F. S.: NATO’s Eastern Agenda in a New Strategic Era. Santa Monica: RAND, 2003.

[5] MICHTA, A. A.: The Limits of Alliance: The United States, NATO and the EU in North and Central Europe. Lanham: Rowan \& Littlefield Publishers, 2006.

[6] OBAMA, H. B: Remarks by President Obama to the Australian Parliament. Office of the White House Press Secretary, 17.11.2011. https://obamawhitehouse.archives.gov/the-pressoffice/2011/11/17/remarks-president-obama-australian-parliament (Downloaded:

26.03.2017)

[7] BIDEN, J.: Remarks by Vice President Biden on America, Central Europe and a Partnership for the 21st Century. Office of the Vice President, 22.10.2009. https://obamawhitehouse. archives.gov/the-press-office/remarks-vice-president-biden-america-central-europe-and-apartnership-21st-century (Downloaded: 08.04.2017)

[8] U.S. Department of Defense: Sustaining U.S. Global Leadership: Priorities for 21st Century Defense. Washington D.C.: U.S. Department of Defense, 2012. http://archive.defense.gov/ news/Defense_Strategic_Guidance.pdf (Downloaded: 08.04.2017)

[9] MAGYARICS T.: A kapcsolatok „,normalizálása” vagy jóindulatú közömbösség? Külügyi Szemle, 2 (2010), 52-69.

[10] KOZARYN, D. L.: Clinton, Yeltsin Confer on NATO, Security Issues. American Forces Press Service, 25.03.1997. http://archive.defense.gov/news/newsarticle.aspx?id=40923 (Downloaded: 09.04.2017)

[11] DIETRICH, W. J.: A Distinctly American Internationalism. In. DIETRICH, W. J.: (ed.): The George W. Bush Foreign Policy Reader. Presidential Speeches with Commentary. New York: Routledge Taylor \& Francis Group, 2015. 26-31.

[12] ERLANGER, S., MYERS, S. L.: NATO Allies Oppose Bush on Georgia and Ukraine. The New York Times, 03.04.2008. http://nytimes.com/2008/04/03/world/europe/03nato.html (Downloaded: 14.05.2017) 
[13] BIDEN, J.: Remarks by Vice President Biden at 45th Munich Conference on Security Policy. Office of the Vice President, 07.02.2009. https://obamawhitehouse.archives.gov/ the-press-office/remarks-vice-president-biden-45th-munich-conference-security-policy (Downloaded: 20.05.2017)

[14] ADAMKUS, V., BUTORA, M., CONSTANTINESCU, E., DEMES, P., DOBROVSKY, L., EÖRSI M., GYARMATI I., HAVEL, V., KACER, R., KALNIETE, S., SCHWARZENBERG, K., KOVAC, M., KRASTEV, I., KWASNIEWSKI, A., LAAR, M., LIIK, K., MARTONYI J., ONYSZKIEWICZ, J., ROTFELD, A., VĪĶE-FREIBERGA, V., VONDRA, A., WALESA, L.: An Open Letter to the Obama Administration from Central and Eastern Europe. Gazeta Wyborcza, 15.07.2009. http://wiadomosci.gazeta.pl/ wiadomosci/1,114881,6825987,An_Open_Letter_to_the_Obama_Administration_from_ Central.html (Downloaded: 22.05.2017)

[15] CLOVER, C.: Clinton Vows to Thwart New Soviet Union. Financial Times, 07.12.2012. https://ft.com/content/a5b15b14-3fcf-11e2-9f71-00144feabdc0 (Downloaded: 23.05.2017)

[16] HERSZENHORN, M. D., KRAMER, E. A.: Russian Adoption Ban Brings Uncertainty and Outrage. The New York Times, 28.12.2012. http://nytimes.com/2012/12/29/world/europe/ russian-adoption-ban-brings-uncertainty-and-outrage.html (Downloaded: 23.05.2017)

[17] SCHWARTZ, I.: Trump Full Speech: This Could Be most Peaceful and Prosperous Century the World Has ever Known. RealClearPolitics, 27.04.2016. http://realclearpolitics.com/ video/2016/04/27/trump_this_could_be_most_peaceful_and_prosperous_century_the_ world_has_ever_known.html (Downloaded: 03.06.2017)

[18] TRUMP, J. D.: Remarks by President Trump in Joint Address to Congress. Office of the White House Press Secretary, 28.02.2017. https://whitehouse.gov/the-pressoffice/2017/02/28/remarks-president-trump-joint-address-congress (Downloaded: 05.06.2017)

[19] TRUMP, J. D.: Presidential Memorandum. Plan to Defeat the Islamic State of Iraq and Syria. Office of the White House Press Secretary, 28.01.2017. https://whitehouse.gov/thepress-office/2017/01/28/plan-defeat-islamic-state-iraq (Downloaded: 17.06.2017)

[20] TRUMP, J. D.: Joint Press Conference of President Trump and NATO Secretary General Stoltenberg. Office of the White House Press Secretary, 12.04.2017. https://whitehouse.gov/ the-press-office/2017/04/12/joint-press-conference-president-trump-and-nato-secretarygeneral (Downloaded: 18.06.2017)

[21] McKERNAN, B.: Nato to Join the US-led Coalition against Isis Fighting in Iraq and Syria. Independent, 25.05.2017. http://independent.co.uk/news/world/europe/nato-us-coalitionisis-iraq-syria-donald-trump-jens-stoltenberg-brussels-visit-a7755751.html (Downloaded: 18.06.2017)

[22] VANDRIVER, J.: NATO Mulls Counter-ISIS Role as Trump Arrives in Brussels. Stars and Stripes, 24.05.2017. https://stripes.com/news/nato-mulls-counter-isis-role-as-trump-arrivesin-brussels-1.469922\#.WUatvuvyjIU (Downloaded: 18.06.2017)

[23] GATES, M. R.: The Security and Defense Agenda (Future of NATO). U.S. Department of Defense, 10.06.2011. http://archive.defense.gov/speeches/speech.aspx?speechid=1581 (Downloaded: 18.06.2017)

[24] SANGER, E., HABERMAN, M.: Donald Trump Sets Conditions for Defending NATO Allies against Attack. The New York Times, 20.07.2016. https://nytimes.com/2016/07/21/us/ politics/donald-trump-issues.html (Downloaded: 18.06.2017) 
[25] TRUMP, J. D.: Remarks by President Trump and President Iohannis of Romania in a Joint Press Conference. Office of the White House Press Secretary, 09.06.2017. https:// whitehouse.gov/the-press-office/2017/06/09/remarks-president-trump-and-presidentiohannis-romania-joint-press (Downloaded: 18.06.2017)

[26] JACOBS, J.: Trump Tells Polish-Americans He’s Committed to Poland's Strength. Bloomberg, 28.09.2016. https://bloomberg.com/politics/articles/2016-09-28/trump-tellspolish-americans-he-s-committed-to-poland-s-strength (Downloaded: 20.06.2017)

[27] HOVET, J., JANCARIKOVA, T.: Central Europeans Confident, Trump Committed to NATO. Reuters, 26.05.2017. http://reuters.com/article/us-usa-nato-centraleuropeidUSKBN18M1XI (Downloaded: 20.06.2017)

[28] PELLERIN, C.: 2018 Budget Request for European Reassurance Initiative Grows to \$4.7 Billion. U.S. Department of Defense, 01.06.2017. https://defense.gov/News/Article/ Article/1199828/2018-budget-request-for-european-reassurance-initiative-grows-to-47billion/ (Downloaded: 21.06.2017)

[29] COPP, T.: US Committed to Europe Force Extension through 2020, Mattis Says. Stars and Stripes, 28.06.2017. https://stripes.com/news/us-committed-to-europe-force-extensionthrough-2020-mattis-says-1.475653\#.WbWyK7JJbIW (Downloaded: 10.09.2017)

[30] SCHMITT, E.: U.S. Troops Train in Eastern Europe to Echoes of the Cold War. The New York Times, 06.08.2017. https://nytimes.com/2017/08/06/world/europe/russia-americamilitary-exercise-trump-putin.html?mcubz=3 (Downloaded: 10.09.2017)

[31] MAYHUGH, T.: U.S., NATO Conclude Saber Strike 17 Exercise. U.S. Department of Defense, 26.06.2017. https://defense.gov/News/Article/Article/1229124/ (Downloaded: 10.09.2017)

[32] MANEA, O.: Top US General: We Need a Military Schengen Zone Inside NATO. Defence Matters, 18.11.2015. http://defencematters.org/news/top-us-general-we-need-a-militaryschengen-zone-inside-nato/416/ (Downloaded: 10.09.2017)

[33] HERSZENHORN, D. M.: Call for 'Military Schengen' to Get Troops Moving. Politico, 04.08.2017. http://politico.eu/article/call-for-military-border-schengen-to-get-troopsmoving-nato-eu-defense-ministers/ (Downloaded: 10.09.2017)

[34] REIF, K.: Missile Defense Review Begins. Arms Control Association, 01.05.2017. https:// armscontrol.org/print/8585 (Downloaded: 20.09.2017)

[35] Transcript of Donald Trump's Speech on National Security in Philadelphia. The Hill, 07.09.2016. http://thehill.com/blogs/pundits-blog/campaign/294817-transcript-of-donaldtrumps-speech-on-national-security-in (Downloaded: 20.09.2017)

[36] DANIELS, J.: Senate Passes $\$ 700$ Billion Defense Policy Bill, Backing Trump Call for Steep Increase in Military Spending. CNBC, 18.09.2017. https://cnbc.com/2017/09/18/ senate-passes-700-billion-defense-policy-bill-backing-trump-call-for-steep-increase-inmilitary-spending.html (Downloaded: 20.09.2017)

[37] Defence Ministry Denies Considering Access to NATO Nuclear Weapons. Radio Poland, 06.12.2015. http://thenews.pl/1/10/Artykul/231762,Defence-Ministry-denies-consideringaccess-to-NATO-nuclear-weapons (Downloaded: 24.09.2017)

[38] HOLLAND, S.: Trump Wants to Make Sure U.S. Nuclear Arsenal at 'Top of the Pack'. Reuters, 23.02.2017. https://reuters.com/article/us-usa-trump-exclusive/trump-wantsto-make-sure-u-s-nuclear-arsenal-at-top-of-the-pack-idUSKBN1622IF (Downloaded: 24.09.2017) 
[39] TRUMP, J. D.: Remarks by President Trump to the People of Poland. Office of the White House Press Secretary, 06.07.2017. https://whitehouse.gov/the-press-office/2017/07/06/ remarks-president-trump-people-poland-july-6-2017 (Downloaded: 14.07.2017)

[40] ADAMOWSKI, J.: The Trump Effect? Defense Buys in Eastern Europe Expected to Ramp up. Defense News, 06.07.2017. http://defensenews.com/articles/the-trump-effect-defensebuys-in-eastern-europe-expected-to-ramp-up (Downloaded: 13.07.2017)

[41] TRUMP, J. D.: Remarks by President Trump at the Three Seas Initiative Summit. Office of the White House Press Secretary, 06.07.2017. https://whitehouse.gov/the-pressoffice/2017/07/06/remarks-president-trump-three-seas-initiative-summit-july-6-2017 (Downloaded: 14.07.2017)

[42] VALDMANIS, R.: U.S. Oil Industry Cheers Trump Energy Pick, Seeks Gas Export Boost. Reuters, 14.12.2016. http://reuters.com/article/us-usa-trump-energy-idUSKBN14316Q (Downloaded: 14.07.2017)

[43] TRUMP, J. D.: Remarks by President Trump at the Unleashing American Energy Event. Office of the White House Press Secretary, 29.06.2017. https://whitehouse.gov/thepress-office/2017/06/29/remarks-president-trump-unleashing-american-energy-event (Downloaded: 14.07.2017)

[44] Trump to Urge European Allies to Dump Russia, Buy U.S. Gas. RadioFreeEurope/ RadioLiberty, 04.07.2017. https://rferl.org/a/trump-urge-eastern-european-allies-polanddump-russia-buy-us-liquified-natural-gas-/28594789.html (Downloaded: 14.07.2017)

[45] STEWART, H., YUHAS, A., WALKER, P.: Donald Trump’s First UK Post-election Interview: Brexit a 'Great Thing’. The Guardian, 16.01.2017. https://theguardian.com/usnews/2017/jan/15/trumps-first-uk-post-election-interview-brexit-a-great-thing (Downloaded: 21.06.2017)

[46] Joint Statement of the Heads of Governments of the V4 Countries "Strong Europe-Union of Action and Trust”. Government of the Czech Republic, 02.03.2017. https://vlada.cz/en/ media-centrum/aktualne/joint-statement-of-the-heads-of-governments-of-the-v4-countriesstrong-europe-_-union-of-action-and-trust_-154008/ (Downloaded: 21.06.2017)

[47] BĂSESCU, T., BILDT, C., DZURINDA, M., EÖRSI M., FOTA, I., GYARMATI I., ILVES, T. H., JUKNEVIČIENĖ, R., KALNIN̦Š, O. Ė., KOWAL, P., ONYSZKIEWICZ, J., PLEVNELIEV, R., SCHWARZENBERG, K., SIKORSKI, R., VAITIEKŪNAS, P., VĪĶE-FREIBERGA, V., VONDRA, A.: Letter to President-elect Donald J. Trump from America’s Allies. The Washington Post, 09.01.2017. https://washingtonpost. com/r/2010-2019/WashingtonPost/2017/01/10/Editorial-Opinion/Graphics/Letter_to_Trump. pdf (Downloaded: 14.07.2017)

[48] BLAKE, A.: The Final Trump-Clinton Debate Transcript, Annotated. The Washington Post, 19.10.2016. https://washingtonpost.com/news/the-fix/wp/2016/10/19/the-final-trumpclinton-debate-transcript-annotated/?utm_term=.63636cdd6b71 (Downloaded: 22.06.2017)

[49] CROWLEY, M.: Trump Changed Views on Ukraine after Hiring Manafort. Politico, 03.08.2016. http://politico.com/story/2016/08/trump-manafort-ukraine-crimearussia-226573 (Downloaded: 22.06.2017)

[50] SENGUPTA, S.: Trump’s U.N. Envoy, Nikki Haley, Condemns Russia’s ‘Aggressive Actions’ in Ukraine. The New York Times, 02.02.2017. https://nytimes.com/2017/02/02/ world/europe/nikki-haley-trump-ukraine-russia-putin.html (Downloaded: 24.06.2017) 
[51] YUHAS, A., KHOMAMI, N., GRIERSON, J., PHIPPS, C.: US Says Russia Bears Responsibility for Assad's Gas Attack—as it Happened. The Guardian, 07.04.2017. https:// theguardian.com/world/live/2017/apr/07/us-syria-response-donald-trump-assad-pentagonlive (Downloaded: 24.06.2017)

[52] CHAZAN, G., SEVASTOPUlO, D.: Putin Praises Trump and Hails New Era of Cooperation. Financial Times, 07.04.2017. https:/ft.com/content/da0629f4-6319-11e7-91a7502f7ee26895?mhq5j=e1 (Downloaded: 14.07.2017)

[53] RAPPEPORT, A., MacFARQUHAR, N.: Trump Imposes New Sanctions on Russia over Ukraine Incursion. The New York Times, 20.06.2017. https://nytimes.com/2017/06/20/world/ europe/united-states-sanctions-russia-ukraine.html (Downloaded: 22.06.2017)

[54] FLEGENHEIMER, M.: New Bipartisan Sanctions Would Punish for Election Meddling. The New York Times, 13.06.2017. https://nytimes.com/2017/06/13/us/politics/senatesanctions-russia.html (Downloaded: 24.06.2017)

[55] BOWDEN, J.: Tillerson Asks for 'Flexibility' in Russian Sanctions. The Hill, 14.06.2017. http://thehill.com/homenews/administration/337796-tillerson-to-congress-dont-passsanctions-that-prevent-dialogue-with (Downloaded: 24.06.2017)

[56] TRUMP, J. D.: Statement by President Donald J. Trump on the Signing of H.R. 3364. Office of the White House Press Secretary, 02.08.2017. https://whitehouse.gov/the-pressoffice/2017/08/02/statement-president-donald-j-trump-signing-hr-3364 (Downloaded: 24.09.2017) 